\title{
EVALUASI KNOWLEDGE MANAGEMENT SYSTEM PADA APLIKASI SIA (SISTEM INFORMASI AKADEMIK) UNIVERSITAS PAMULANG
}

\author{
Wasis Haryono \\ Teknik Informatika, Teknik \\ Universitas Pamulang \\ Wasish@Unpam.ac.id
}

\begin{abstract}
ABSTRAK
Sistem informasi akademik merupakan lalu lintas komunikasi antara Dosen, mahasiswa, dan aktivitas yang berhubungan dengan kebutuhan mahasiswa dalam kegiatan perkuliahan. Sistem informasi akademik my Unpam ini terdiri dari my Dosen, my Unpam, perpustakaan, e-learning, helpdesk dan PMB online. Untuk mengetahui kebergunaan pengetahuan pada sistem akademik ini perlu dilakukan analisis knowledge management system berupa konversi pengetahuan tacit to tacit dan tacit to explicit yang digunakan sebagai tujuan penelitian ini. Metode penelitian ini yaitu studi pustaka dan observasi atau analisis terhadap website akademik Unpam. Sistem informasi akdemik UNPAM telah menerapkan knowledge Management System dengan beberapa konversi pengetahuannya. Konversi yang digunakan yaitu tacit to tacit dan tacit to explicit. Hasil persentase pengetahuan yaitu my Dosen sebanyak 25\%, my UNPAM $35 \%$, E-Learning $10.5 \%$, Perpustakaan sebanyak 11.8\%, Helpdesk $2 \%$ dan PMB $14.4 \%$. Dengan demikian nilai tertinggi dan terbanyak konversi pengetahuan yaitu pada halaman web My Unpam yang sering diakses oleh mahasiswa.
\end{abstract}

Kata Kunci: Sistem Informasi Akademik, Tacit, Explicit, Knowledge Management System

\begin{abstract}
Academic information system is the communication traffic between lecturers, students, and activities related to the needs of students in lecturing activities. My Unpam academic information system consists of my lecturer, my Unpam, library, e-learning, helpdesk and PMB online. To know the usefulness of knowledge in the academic system needs to be done knowledge management system analysis in the form of tacit to tacit knowledge conversion and tacit to explicit used as the purpose of this study. This research method is literature study and observation or analysis on academic website Unpam. The information system of UNPAM has applied the knowledge management system with some of its knowledge conversion. The conversion used is tacit to tacit and tacit to explicit. The result of knowledge percentage is my lecturer 25\%, my UNPAM 35\%, E-Learning 10.5\%, Library $11.8 \%$, $2 \%$ Helpdesk and PMB 14.4\%. Thus, the highest value and the most knowledge conversion is on the My Unpam web page that is often accessed by students.
\end{abstract}

Keywords: Academic Information System, Tacit, Explicit, Knowledge Management System

http://dx.doi.org/10.15408/jti.v11i2.7983 


\section{PENDAHULUAN}

Akademik merupakan seluruh lembaga pendidikan formal baik pendidikan anak usia dini, pendidikan dasar, pendidikan menengah, pendidikan kejuruan maupun perguruan tinggi yang menyelenggarakan pendidikan vokasi dalam suatu cabang atau sebagian cabang ilmu pengetahuan, teknologi dan seni tertentu [1]. Dalam dunia pendidikan umumnya informasi masih dilakukan dengan mengolah data secara manual, sementara proses kegiatan dan administrasi akademik yang dilakukan, dengan jumlah pemakai yang sangat banyak dan keterbatasan sumberdaya manusia yang ada di unit pelaksana, dapat mengakibatkan kegiatan pengolahan data menjadi sulit. Pengolahan data secara manual juga keakuratan data yang rendah [2]. Sistem manajemen pengetahuan atau Knowlege Management System (KMS) sangat diperlukan untuk pertukaran informasi pada sistem akademik. Untuk itu perlu dilakukan evaluasi KMS, sehingga dapat diketahui sejauh mana peranan konversi pengetahuan yang diterapkan pada Sistem Informasi akademik terutama Universitas Pamulang. Peranan konversi pada penelitian ini berupa konversi pengetahuan yang tersedia yaitu tacit to tacit, tacit to explicit, explicit to tacit, explicit to explicit [3]. Tacit merupakan pengetahuan yang didapat setelah menyimpulkan sesuatu berupa pemahaman dan explicit knowledge merupakan pengetahuan secara terlulis yaitu informasi-informasi yang didapat mahasiswa melalui sistem akademik yang digunakan, Tujuan dari penelitian ini adalah mengetahui penerapan Knowledge Management System pada sistem akademik Universitas Pamulang. Penelitian ini menggunakan metode studi pustaka dan studi lapangan dengan mengamati SIA UNPAM sebagai objek penelitian untuk mendapatkan data-data serta hal-hal penting yang berhubungan dengan Knowledge Management System pada sistem akademik UNPAM.

Universitas Pamulang telah menyediakan berbagai macam fasilitas seperti laboratorium dan perpustakaan serta sistem informasi yang menunjang kegiatan akademik mahasiswa. Sistem informasi yang merekam data dan sarana serta prasarana secara lengkap dan terintegrasi [4]. Proses perekam data dan informasi tersebut diperlukan sebagai KMS (Knowledge Management System). Dimana KMS dapat melakukan sharing pengetahuan melalui informasi yang didapat pada Sistem Akademik. sehingga peneliti mengambil judul "Evaluasi Knowledge Management System Pada Aplikasi SIA (Sistem Informasi Akademik) Universitas Pamulang".

\section{TINJAUAN PUSTAKA}

\subsection{Akademik}

Akademik adalah seluruh lembaga pendididkan formal baik pendidikan anak usia dini, pendidikan dasar, pendidikann menengah, pendidikan kejuruan, maupun perguruan tinggi yang menyelenggarakan pendidikan vokasi dalam suatu cabang atau sebagian cabang ilmu pengetahuan, teknologi, dan seni tertentu [1]. Sistem Informasi Akademik merupakan sistem yang mengolah data dan melakukan proses kegiatan akademik yang melibatkan antara siswa, guru, administrasi akademik, penilaian dan data atribut laiinnya. Sistem informasi akademik melakukan kegiatan administrasi akademik,melakukan proses-proses transaksi belajar-mengajar antara guru dan siswa, melakukan proses administrasi akademik yang baik menyangkut kelengkapan dokumen dan biaya yang muncul pada kegiatan registrasi ataupun kegiatan operasional harian administrasi akademik [5].

\subsection{Knowledge}

Knowledge merupakan pengalaman, nilai, informasi kontektual pandangan serta intuisi mendasar yang menciptakan situasi terbaru melalui melalui informasi yang diperoleh. Knowledge bukan hanya dokumen tetapi rutinitas dan proses, praktek pengolahan informasi [6]. Jenis-jenis knowledge diantaranya:

\section{Explicit Knowledge}

Explicit Knowledge merupakan sesuatu yang dapat diekspresikan dengan katakata, angka serta disampaikan dalam bentuk ilmiah, spesifikasi, manual dan sebagainya. Knowledge jenis ini dapat segera diteruskan dari satu individu ke individu lainnya secara formal dan sistematis. Explicit knowledge juga dapat dijelaskan sebagai suatu proses, metode, cara, pola bisnis dan pengalaman desain dari suatu produksi. Sehingga Explicit knowledge merupakan sebuah dokumen baik tercetak pada buku maupun secara elektronik. 
2. Tacit Knowledge

Tacit knowledge adalah pengetahuan yang terdapat pada pakar baik individu maupun masyarakat. Tacit knowledge bersifat sangat personal dan sulit dirumuskan. Pengetahuan ini berupa perasaan pribadi, intuisi, bahasa tubuh, pengaman fisik serta petunjuk praktis (Rule of Thumb). Sehingga Tacit knowledge berupa pengalaman dari pakar yang disampaikan ke orang lain.

\subsection{Knowledge Management}

Manajemen Pengetahuan

(Knowledge Management) terdiri dari sistem perangkat lunak serta mengintegrasikan dan menyebarkan informasi bagi pengguna untuk proses pembelajaran dan membuat keputusan [7]. Di samping itu manajemen pengetahuan merupakan bidang studi yang dapat meningkatkan proses berbagi, penyaluran, menciptakan, menangkap, dan pemahaman pengetahuan sehingga pengetahuan tersebut tidak sia-sia [8]. Manajemen pengetahuan merupakan hasil maksimal dari sumber pengetahuan yang dibutuhkan oleh seseorang [9]. Manajemen pengetahuan juga merupakan proses pengelolaan pengetahuan dengan cara penangkapan, penyimpanan, dan penyebaran pengetahuan dengan menggunakan media teknologi informasi [10].

\subsection{Knowledge Management System}

Knowledge Management System atau sistem manajemen pengetahuan adalah integrasi teknologi dan mekanisme yang dikembangkan untuk mendukung proses manajemen pengetahuan. Sistem manajemen pengetahuan dapat diklasifikasikan ke dalam empat jenis yaitu aplikasi pengetahuan, menangkap pengetahuan, berbagi pengetahuan, penemuan pengetahuan, maka pengetahuan yang terdapat pada sistem tersebut bisa digunakan sesuai dengan bidangnya masingmasing [9].

\subsection{Manfaat Knowledge Management System}

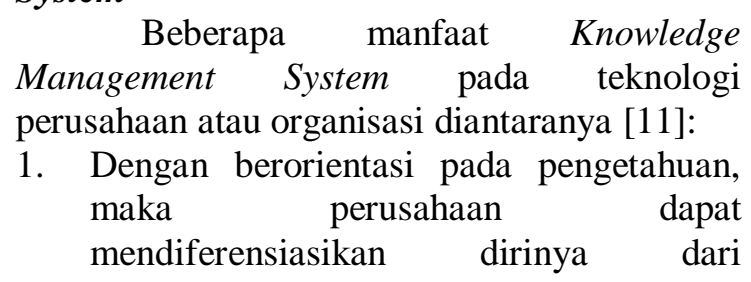

perusahaan lain dan dapat bersaing secara efektif di pasar.

2. Perusahaan dapat memperoleh manfaat tambahan yang berasal dari kemajuan operasional, yang fokusnya pada aktivitas internal. Manfaat ini meliputi penghematan biaya, efisiensi proses, perubahan dalam proses manajemen misalnya perubahan perilaku, dan manfaat dari penggunaan kembali pengetahuan oleh anggota lain sehingga dapat diperoleh standar kualitas yang tinggi.

3. Perusahaan dapat memperoleh manfaat tambahan yang berasal dari peningkatan pasar, yang fokusnya pada aktivitas eksternal seperti meningkatkan kinerja penjualan, menghemat biaya produk dan jasa serta meningkatkan kepuasan konsumen

\subsection{Konversi Pengetahuan}

Gambar 1 merupakan Konversi pengetahuan ini terdiri dari 4 tahap. Tahap pertama yaitu tacit knowledge to tacit knowledge disebut socialization. Tahap kedua yaitu tacit knowledge to explicit knowledge disebut externalization. Tahap ketiga yaitu tacit knowledge to explicit knowledge yang disebut combination. Tahap keempat yaitu tacit knowledge to explicit knowledge yang disebut internalization. Penjelasan lebih lanjut sebagai berikut:

1. Tacit knowledge to tacit knowledge disebut socialization

Sosialisasi merupakan kegiatan berbagi tacit knowledge antar individu. Kegiatan ini disebarkan melalui kegiatan bersama seperti pada saat tinggal bersama maupun meluangkan waktu bersama bukan melalui tulisan. Dengan demikian, dalam kasus tertentu tacit knowledge hanya bisa disebarkan jika seseorang yang lebih besar memiliki pengetahuan tacit dari orang lain. Sehingga tacit to tacit knowledge yaitu menyerap pengalaman orang lain yang terapkan pada kehidupan seseorang.

2. Tacit knowledge to explicit knowledge disebut externalization

Externalisasi membutuhkan penyajian tacit knowledge ke dalam bentuk yang lebih umum sehingga dapat dipahami oleh orang lain.

3. Tacit knowledge to explicit knowledge 
yang disebut combination

Mengorganisasikan kumpulan explicit knowledge ke dalam satu bentuk media yang lebih sistematis melalui penambahan knowledge baru, kombinasi dan kategorisasi pengetahuan yang telah terkumpul. Kombinasi knowledge dapat difasilitasi melalui media seperti dokumen, pertemuan, komunikasi melalui telepon maupun perangkat jaringan yang terhubung.

4. Explicit knowledge to tacit knowledge yang disebut internalization

Transformasi knowledge dari Explicit knowledge to tacit knowledge. Contohnya dengan proses belajar yang kemudiaan diikuti dengan "learning by doing”. Ketika pengalaman melalui sosialisasi, externalization dan kombinasi diinternalisasi ke dalam knowledge tacit individu dalam bentuk model mental yang dibagikan menjadi aset pengetahuan yang bernilai yang membentuk pengetahuan baru dalam diri individu.
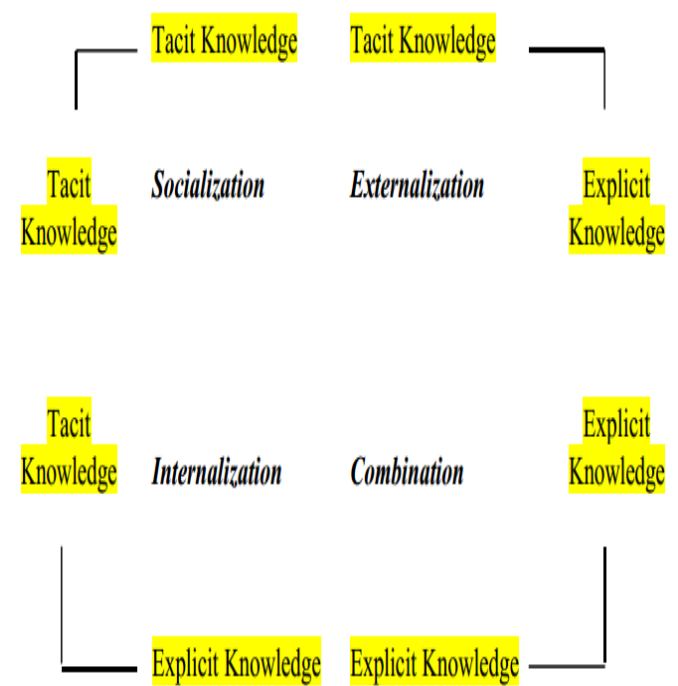

Gambar 1. Model konversi Nonaka

Takeuchi

\subsection{Arsitektur Knowledge Management System}

Terdapat beberapa layer pada arsitektur Knowledge Management System[12] yaitu:

1. Layer pertama adalah user yang dalam hal ini adalah individuindividu dari mahasiswamahasiswa, Dosen, pembimbing, alumni, pakar, dan sebagainya menjadi sumber knowledge.

2. Layer kedua adalah interface layer client menggunakan J2ME yang berbasis teknologi mobile sehingga dapat dengan mudah diakses di smartphone.

3. Layer ketiga adalah communication/transport layer server yang menangani layanan terhadap permintaan dari layer client.

4. Layer keempat adalah kumpulan database dari Knowledge Management system. Kumpulan database ini sangat penting dalam suatu knowledge management system untuk penyimpanan sumber pengetahuan yang berupa database dokumen, database diskusi, sistem file yang menyimpan file fisik.

\subsection{Siklus Manajemen Pengetahuan}

Siklus Manajemen pengetahuan merupakan fase yang menjelaskan tahapan penangkapan (Capture), penciptaan (Creation), kodifikasi (Codification), penyebarluasan (Sharing) serta pengaksesan (Accesing). Siklus manajemen pengetahuan inipun melibatkan aplikasi dan penggunakaan kembali pengetahuan yanga ada pada sebuah sistem, sehingga mengubah informasi menjadi pengetahuan yang bermanfaat [13]

Siklus manaejemen pengetahuan merupakan siklus manajemen Bukowitz and Williams yang terdiri dari Get, Use, Learn, Contribute, build/sustain, divest dan Assess. Siklus ini menjelaskan bagaiman organisasi menghasilkan, memelihara dan menyebarluaskan strategi menghasilkan pengetahuan yang bernilai. Berikut penjelasan dari masing-masing proses siklus:

a. Get adalah proses mencari informasi yang diperlukan untuk pengambilan keputusan, pemecahan masalah atau untuk inovasi. Proses Get ini juga tahapan dimana seseorang ingin mencari pengetahuan yang akan digunakan.

b. Use adalah bagaimana menggunakan informasi untuk berinovasi baik individual maupun kelompok. Disamping itu, Use 
merupakan proses penggunaan pengetahuan untuk dipelajari lebih lanjut.

c. Learn adalah bagaimana organisasi dapat belajar dari pengalaman, baik dari kesuksesan (best practice) maupun kegagalan (lesson learned) untuk menciptakan keunggulan (Competitive advantage). Learn juga merupakan cara pandang seseorang terhadap pengatahuan apakah bermanfaat atau tidak

d. Contribute adalah memberikan pengetahuan yang diperoleh dari hasil pembelajaran (learning) untuk individu lainnya. Contribute juga merupakan proses sharing pengetahuan antar individu.

e. Assess adalah evaluasi dari manusianya (kompetensi), pelanggan (hubungan pelanggan), modal perusahaan (dasar-dasar pengetahuan, proses bisnis, infrastruktur teknologi, nilai norma, budaya) dan modal intelektual (hubungan antara manusia, pelanggan, dan modal organisasi). Assess memiliki keterlibatan antara berbagai komponen, dimana komponen tersebut saling berhubungan.

f. Build and Sustain adalah untuk meyakinkan bahwa modal intelektual perusahaan dimasa yang akan datang akan membawa perusahaan tetap bertahan dan bersaing. Hal ini bertujuan untuk menyampaikan informasiinformasi penting yang akan digunakan untuk pengguna.

g. Divest adalah tempat pembuangan pengetahuan yang sudah tidak terpakai lagi (tidak bernilai). Hal ini biasanya diletakkan pada tampilan akhir, karena informasi yang disampaikan telah melewati batas waktu atau sudah tidak update lagi.

\section{METODOLOGI}

Metode pengumpulan data yang umum digunakan dalam suatu penelitian adalah sebagai berikut:

\section{Observasi}

Observasi merupakan salah satu teknik pengumpulan data yang cukup efektif untuk mempelajari suatu sistem. Observasi merupakan pengumpulan data dengan cara melakukan pencatatan secara cermat dan sistematik. Untuk mendapatkan observasi secara sistematis peneliti harus mempunyai latar belakang atau pengetahuan yang luas tentang obyek penelitian, mempunyai dasar teori dan sikap obyektif. Observasi yang dilakukan pada penelitian ini yaitu dengan meneliti sistem akademik universitas Pamulang yaitu Unpam.ac.id sehingga diperoleh jumlah konversi pengetahuan pada universitas pamulang.

\section{Studi Pustaka}

Pengumpulan data dengan menggunakan atau mengumpulkan sumber-sumber tertulis, dengan cara membaca, mempelajari dan mencatat hal-hal penting dari buku dan jurnal yang bersifat tercetak maupun elektronik yang berhubungan dengan masalah yang sedang dibahas guna memperoleh gambaran secara teoritis yang dapat menunjang pada penyusunan penelitian.

\section{HASIL DAN PEMBAHASAN}

Analisa konversi pengetahuan

Analisa dan konversi pengetahuan ini dilakukan dengan analisa halaman my Dosen, my Unpam, e-learning, perpustakaan, helpdesk dan PMB online.

a. My Dosen

Tabel 2 merupakan konversi pengetahuan my UNPAM pada tabel ini terdapat 16 halaman dengan jumlah konversi sebanyak 27. Konversi pengetahuan terdiri dari 4 konversi tacit to explicit dan 23 tacit to tacit. Konversi tacit too tacit artinya pengetahuan tersebut hanya bisa dilihat dan diserap sedangkan konversi tacit to explicit artinya pengetahuan tersebut bisa di unduh dan digunakan untuk keperluan akademik. Tabel 1 merupakan konversi pengetahuan my Dosen dengan jumlah 19. 
Tabel 1. Konversi my Dosen

\begin{tabular}{|c|c|c|}
\hline Halaman & \multicolumn{2}{|c|}{ Konversi } \\
\hline Login My Dosen & $\begin{array}{l}\text { Tacit to } \\
\text { knowledge }\end{array}$ & tacit \\
\hline Referensi PAK & $\begin{array}{l}\text { Tacit to } \\
\text { knowledge }\end{array}$ & tacit \\
\hline Referensi SISKEMU & $\begin{array}{l}\text { Tacit to } \\
\text { knowledge }\end{array}$ & tacit \\
\hline Input kegiatan & $\begin{array}{l}\text { Tacit to tacit } \\
\text { to explicit } k n\end{array}$ & $\begin{array}{l}\text { tacit } \\
\text { edge }\end{array}$ \\
\hline Tambah kegiatan & $\begin{array}{l}\text { Tacit to } \\
\text { knowledge }\end{array}$ & tacit \\
\hline Laporan kegiatan & $\begin{array}{l}\text { Tacit to } \\
\text { knowledge }\end{array}$ & tacit \\
\hline Pengajuan jabatan & $\begin{array}{l}\text { Tacit to } \\
\text { knowledge }\end{array}$ & tacit \\
\hline Laporan pengajuan & $\begin{array}{l}\text { Tacit to } \\
\text { knowledge }\end{array}$ & tacit \\
\hline $\begin{array}{l}\text { Input kegiatan pada } \\
\text { SISKEMU }\end{array}$ & $\begin{array}{l}\text { Tacit to } \\
\text { knowledge }\end{array}$ & tacit \\
\hline Tambah kegiatan & $\begin{array}{l}\text { Tacit to } \\
\text { knowledge }\end{array}$ & tacit \\
\hline Laporan kegiatan & $\begin{array}{l}\text { Tacit to } \\
\text { knowledge }\end{array}$ & taci \\
\hline Penilaian SISKEMU & $\begin{array}{l}\text { Tacit to } \\
\text { knowledge }\end{array}$ & tacit \\
\hline $\begin{array}{l}\text { Jadwal mengajar dan } \\
\text { input nilai SIA }\end{array}$ & $\begin{array}{l}\text { Tacit to tacit } \\
\text { to explicit } k n\end{array}$ & $\begin{array}{l}\text { taci } \\
\text { edge }\end{array}$ \\
\hline Entry perubahan nilai & $\begin{array}{l}\text { Tacit to } \\
\text { knowledge }\end{array}$ & tacit \\
\hline Jadwal remedial & $\begin{array}{l}\text { Tacit to } \\
\text { knowledge }\end{array}$ & tacit \\
\hline Laporan absensi & $\begin{array}{l}\text { Tacit to } \\
\text { knowledge }\end{array}$ & tacit \\
\hline Laporan detail absensi & $\begin{array}{l}\text { Tacit to } \\
\text { knowledge }\end{array}$ & tacit \\
\hline Jumlah & 19 & \\
\hline
\end{tabular}

b. My UNPAM

My Unpam merupakan sistem akademik yang menjadik aktifitas mahasiswa. Mahasiswa yang sudah terdaftar di Unpam wajib mempunyai username dan password yang berhubungan dengan aktivitas kegiatasn mahasiswa berupa nilai mata kuliah, dokumen KRS, surat keterangan aktif kuliah dan lainlain.

Tabel 2. Konversi my UNPAM

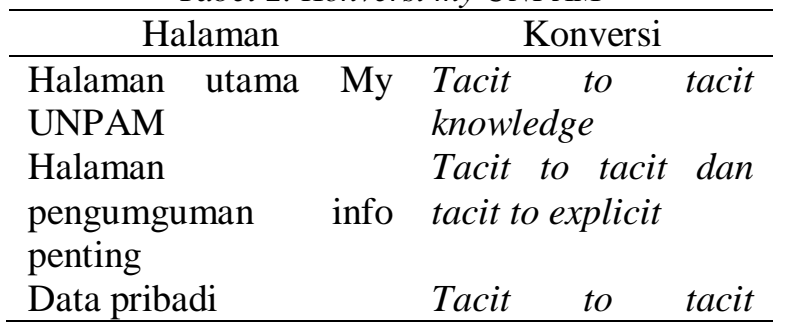

\begin{tabular}{|c|c|}
\hline & knowledge \\
\hline $\begin{array}{l}\text { Kartu rencana studi } \\
\text { akademik }\end{array}$ & $\begin{array}{l}\text { Tacit to tacit dan } \\
\text { tacit to explicit }\end{array}$ \\
\hline $\begin{array}{l}\text { Halaman cetak KRS } \\
\text { remedial }\end{array}$ & $\begin{array}{l}\text { Tacit to tacit dan } \\
\text { tacit to explicit }\end{array}$ \\
\hline Jadwal kuliah & $\begin{array}{l}\text { Tacit to tacit dan } \\
\text { tacit to explicit }\end{array}$ \\
\hline Tampilan jadwal kuliah & $\begin{array}{l}\text { Tacit to tacit } \\
\text { knowledge }\end{array}$ \\
\hline $\begin{array}{l}\text { Proses cetak jadwal } \\
\text { kuliah }\end{array}$ & $\begin{array}{l}\text { Tacit to explicit } \\
\text { knowledge }\end{array}$ \\
\hline $\begin{array}{l}\text { Kartu ujian tengah } \\
\text { semester }\end{array}$ & $\begin{array}{l}\text { Tacit to tacit dan } \\
\text { tacit to explicit }\end{array}$ \\
\hline $\begin{array}{l}\text { Kartu Ujian akhir } \\
\text { semester }\end{array}$ & $\begin{array}{l}\text { Tacit to tacit dan } \\
\text { tacit to explicit }\end{array}$ \\
\hline Kartu hasil studi & $\begin{array}{l}\text { Tacit to tacit dan } \\
\text { tacit to explicit }\end{array}$ \\
\hline Cetak kartu hasil studi & $\begin{array}{l}\text { Tacit to tacit dan } \\
\text { tacit to explicit }\end{array}$ \\
\hline Rangkuman nilai & $\begin{array}{l}\text { Tacit to tacit dan } \\
\text { tacit to explicit }\end{array}$ \\
\hline Cetak nilai & $\begin{array}{l}\text { tacit to explicit } \\
\text { knowledge }\end{array}$ \\
\hline Laporan keuangan & $\begin{array}{l}\text { Tacit to tacit dan } \\
\text { tacit to explicit }\end{array}$ \\
\hline Dokumen unduh & $\begin{array}{l}\text { Tacit to tacit dan } \\
\text { tacit to explicit }\end{array}$ \\
\hline Jumlah & 27 \\
\hline
\end{tabular}

c. Perpustakaan

Tabel 3 merupakan konversi pengetahuan perpustakaan dengan jumlah 9 .

Tabel 3. Konversi perpustakaan

\begin{tabular}{|c|c|c|}
\hline Halaman & \multicolumn{2}{|c|}{ Konversi } \\
\hline $\begin{array}{l}\text { Halaman utama } \\
\text { perpustakaan }\end{array}$ & $\begin{array}{l}\text { Tacit to } \\
\text { knowledge }\end{array}$ & tacit \\
\hline Library news & $\begin{array}{l}\text { Tacit to } \\
\text { knowledge }\end{array}$ & tacit \\
\hline Info perpustakaan & $\begin{array}{l}\text { Tacit to } \\
\text { knowledge }\end{array}$ & tacit \\
\hline Library location & $\begin{array}{l}\text { Tacit to } \\
\text { knowledge }\end{array}$ & tacit \\
\hline Bantuan pencarian & $\begin{array}{l}\text { Tacit to } \\
\text { knowledge }\end{array}$ & tacit \\
\hline Masuk pustakawan & $\begin{array}{l}\text { Tacit to } \\
\text { knowledge }\end{array}$ & tacit \\
\hline About slims & $\begin{array}{l}\text { Tacit to } \\
\text { knowledge }\end{array}$ & tacit \\
\hline Jumlah & 9 & \\
\hline
\end{tabular}




\section{d. Helpdesk}

Tabel 4 merupakan konversi pengetahuan helpdesk yang terdiri dari 2.

Tabel 4. Konversi helpdesk

\begin{tabular}{|c|c|c|c|}
\hline \multicolumn{2}{|c|}{ Halaman } & \multicolumn{2}{|c|}{ Konversi } \\
\hline $\begin{array}{l}\text { Halaman } \\
\text { helpdesk }\end{array}$ & utama & $\begin{array}{l}\text { Tacit to } \\
\text { knowledge }\end{array}$ & tacit \\
\hline $\begin{array}{l}\text { Halaman } \\
\text { knowledgebase }\end{array}$ & & $\begin{array}{l}\text { Tacit to } \\
\text { knowledge }\end{array}$ & tacit \\
\hline Jumlah & & 2 & \\
\hline
\end{tabular}

e. Penerimaan mahasiswa baru

Tabel 5. Konversi penerimaan mahasiswa baru

\begin{tabular}{|c|c|}
\hline Halaman & Konversi \\
\hline registrasi & Tacit \\
\hline PMB & knowledge \\
\hline $\begin{array}{l}\text { Halaman } \\
\text { pendaftar }\end{array}$ & $\begin{array}{l}\text { Tacit to } \\
\text { knowledge }\end{array}$ \\
\hline $\begin{array}{l}\text { Halaman } \\
\text { pendaftar } \\
\text { pemberkasan }\end{array}$ & $\begin{array}{l}\text { Tacit to tacit dan } \\
\text { tacit to explicit } \\
\text { knowledge }\end{array}$ \\
\hline Cetak kartu ujian & $\begin{array}{l}\text { Tacit to tacit dan } \\
\text { tacit to explicit } \\
\text { knowledge }\end{array}$ \\
\hline $\begin{array}{l}\text { Informasi ruang tes } \\
\text { PMB }\end{array}$ & $\begin{array}{l}\text { Tacit to tacit dan } \\
\text { tacit to explicit } \\
\text { knowledge }\end{array}$ \\
\hline Informasi hasil tes & $\begin{array}{l}\text { Tacit to } \\
\text { knowledge }\end{array}$ \\
\hline $\begin{array}{l}\text { Kelengkapan berkas } \\
\text { PMB }\end{array}$ & $\begin{array}{l}\text { Tacit to tacit dan } \\
\text { tacit to explicit } \\
\text { knowledge }\end{array}$ \\
\hline Jumlah & 11 \\
\hline
\end{tabular}

Mahasiswa yang hendak mendaftarkan diri ke Universitas Pamulang harus mengakses halaman penerimaan mahasiswa baru. Halaman ini terdiri dari halaman input data, cetak kartu ujian, informasi ruang tes informasi hasil tes dan kelengkapan berkas PMB. Dokumen tersebut berupa dokumen unduh dan informasi yang berhubungan dengan penerimaan mahasiawa baru tersebut. Tabel 5 merupakan konversi pengetahuan penerimaan siswa baru sebanyak 11 .

\section{f. E-Learning}

E-learning merupakan halaman untuk berdiskusi online antara mahasiswa dan Dosen. Halaman ini terdiri dari halaman utama $e$ learning. Halaman dashboard berupa pengumuman info penting, Site pages Kalender merupakan kalender online $e$ learning. Current Cource merupakan halaman mata kuliah yang diajarkan oleh Dosen yang bersangkutan. Halaman Forum diskusi merupakan halaman diskusi dengan beberapa pertanyaan yang wajib untuk dijawab oleh mahasiswa dengan jadwal yang telah ditentukan. Tabel 6 halaman e-learning dengan 8 konversi pengetahuan.

Tabel 6. Konversi e-learning

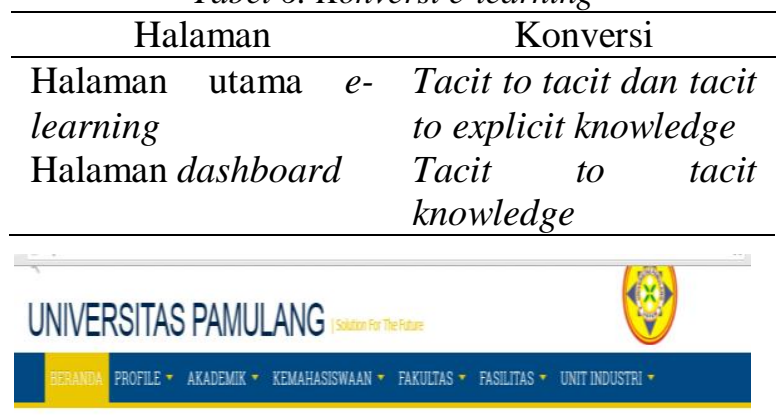
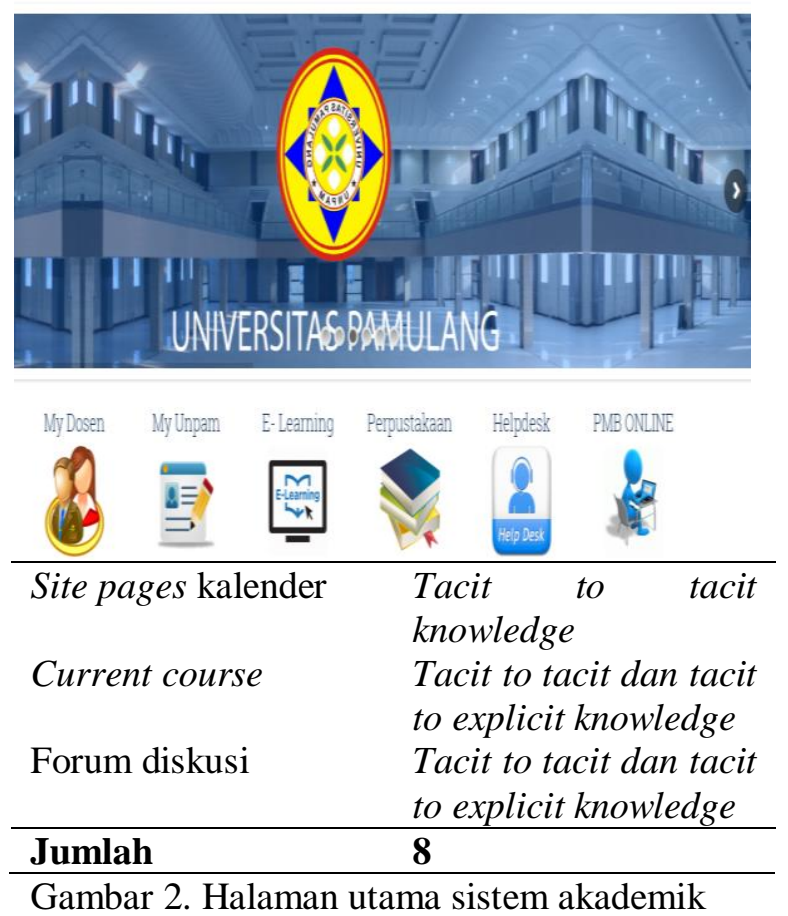

Gambar 2. Halaman utama sistem akademik 


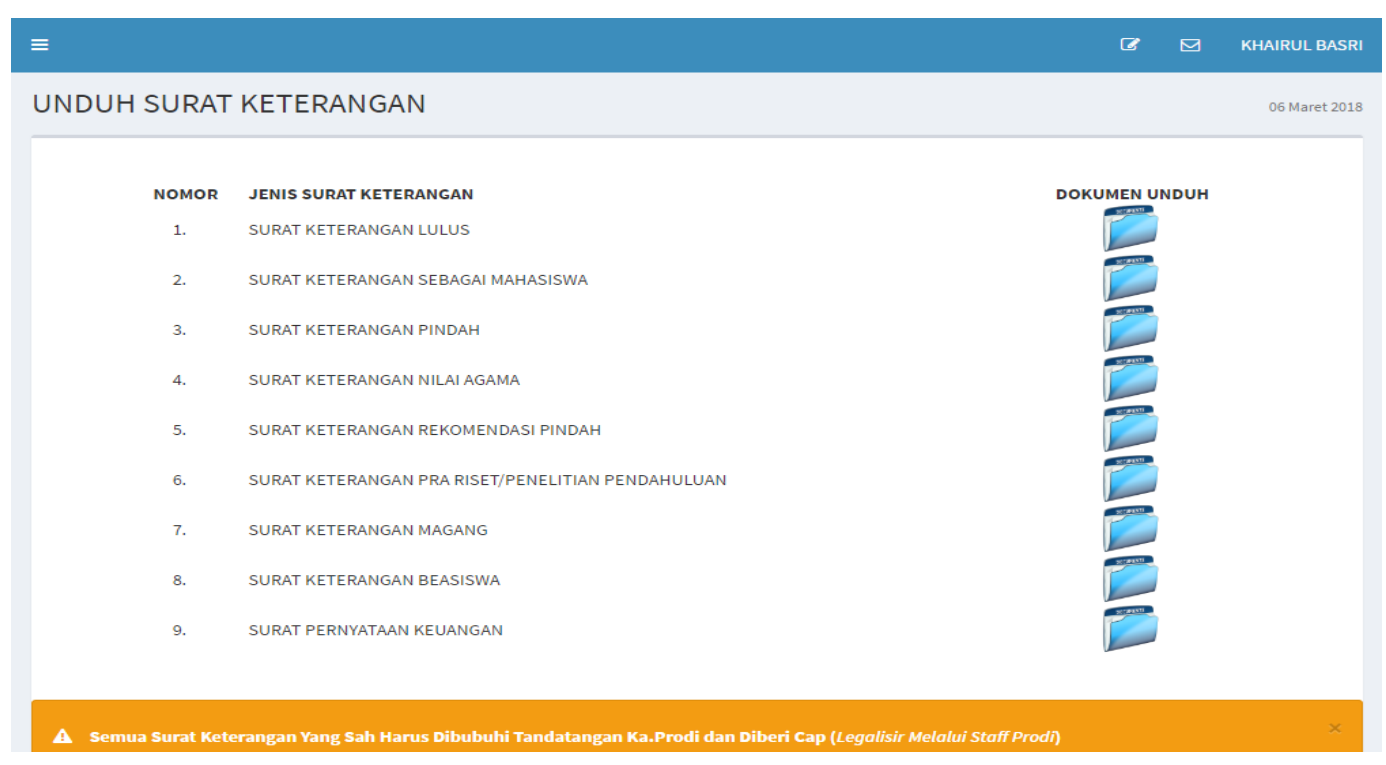

Gambar 3. Unduh surat keterangan

\section{Jumlah}

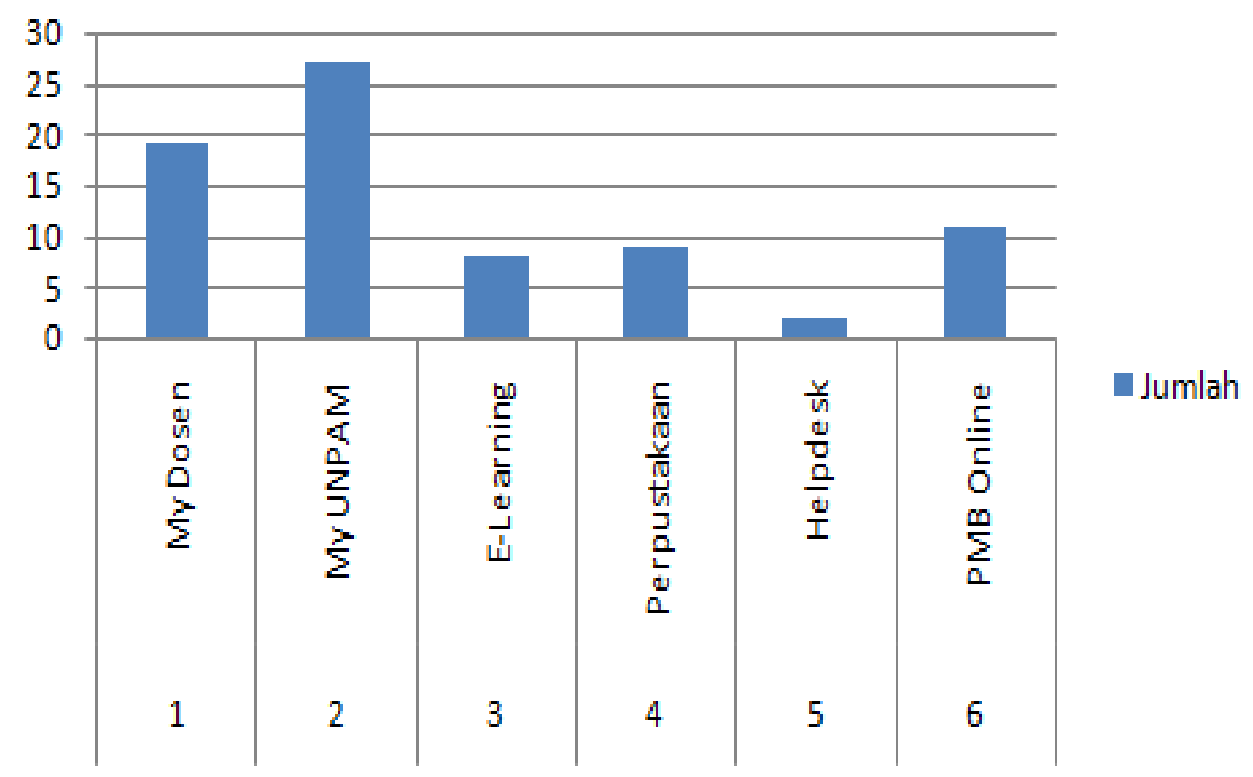

Gambar 4. Grafik akhir konversi pengetahuan

Gambar 2 merupakan halaman utama sistem akademik Universitas Pamulang. Halaman ini terdiri dari 6 bagian, yaitu my Dosen, my Unpam, e-learning, perpustakaan, helpdesk dan PMB online. Gambar 3 merupakan halaman dokumen unduh surat keterangan. Halaman ini terdiri dari surat keterangan lulus, surat keterangan sebagai mahasiswa, surat keterangan pindah, surat keterangan nilai agama, surat keterangan rekomendasi pindah, surat keterangan penelitian pendahuluan, surat keterangan magang, surat keterangan beasiswa, surat pernyataan keuangan. Surat tersebut berhubungan dengan dokumen aktivitas mahasiswa, sehingga surat tersebut terdapat pada halaman my UNPAM.

Gambar 4 merupakan grafik akhir konversi pengetahuan. Pada gambar tersebut terdapat konversi pengetahuan sebanyak 19 mewakili jumlah konversi berupa tacit to tacit dan tacit to explicit mewakili my Dosen, 27 mewakili my Unpam, 8 mewakili E-Learning, 9 mewakili Perpustakaan, 2 mewakili Helpdesk, 11 mewakili PMB online. 


\section{Jumlah}

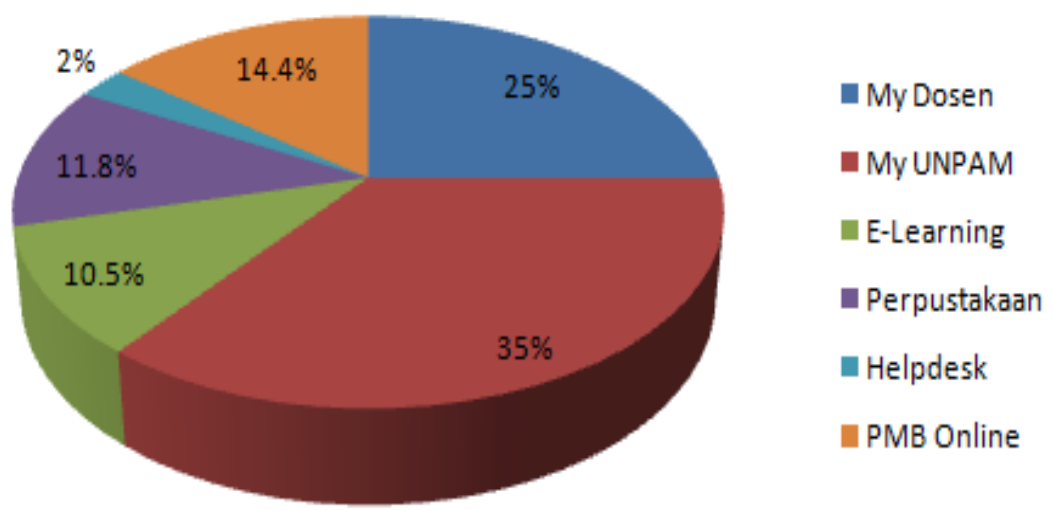

Gambar 5. Diagram lingkaran konversi

Gambar 5 merupakan diagram lingkaran konversi pengetahuan. Diagram lingkaran dengan nilai tertinggi pada konversi pengetahuan my Unpam. Diagram lingkaran dengan persentase my Dosen sebanyak 25\%, my UNPAM $35 \%$, E-Learning $10.5 \%$, Perpustakaan sebanyak $11.8 \%$, Helpdesk $2 \%$ dan PMB 14.4\%. Persentase dihasilkan dari jumlah dibagi total keseluruhan setelah itu dikali $100 \%$.

\section{PENUTUP}

Kesimpulan dan saran pada penelitian ini terdiri dari:

1. Sistem informasi akdemik UNPAM telah menerapkan knowledge Management System dengan beberapa konversi pengetahuannya.

2. Konversi yang digunakan yaitu tacit to tacit dan tacit to explicit.

3. Hasil persentase pengetahuan yaitu my Dosen sebanyak 25\%, my UNPAM $35 \%$, E-Learning $10.5 \%$, Perpustakaan sebanyak $11.8 \%$, Helpdesk $2 \%$ dan PMB $14.4 \%$.

4. Dengan demikian nilai tertinggi dan terbanyak konversi pengetahuan yaitu pada halaman web My Unpam yang sering diakses oleh mahasiswa.

5. Untuk penelitian lebih lanjut perlu mencoba analisis dengan metode yang lain.

\section{DAFTAR PUSTAKA}

[1] Subhansyah N. 2011. Perancangan Sistem Akademik Sekolah Berbasis Teknologi Mobile Web ( Studi Kasus: SMA Muhammadiyah Tangerang). Fakultas Sains dan Teknologi, Universitas Islam Negeri Syarif Hidayatullah Jakarta.

[2] Wuryantoro A. 2009. Pengembangan Sistem Informasi Manajemen Akademik Berbasis Web. Fakultas Matematika dan Ilmu Pengetahuan Alam, Institut Pertanian Bogor.

[3] Nonaka IT, Takeuchi. 1995. The Knowledge Creating Company: How Japanese Companies Create the Dynamics of Innovation. Oxford. Oxford University Press.

[4] Bhayuaji AR.2014. Modul akademik dan modul sarana dan Prasarana Dalam Sistem Informasi Akreditasi Program Studi (SIAPS) untuk Departemen Ilmu Komputer. [Skripsi]. Bogor(ID): Institut Pertanian Bogor.

[5] Jamaliyah. 2011. Sistem informasi Akademikberbasis Client Server (Studi Kasus: Madrasah Tsanawiyah AnNizhamiyyah Cileungsi). Fakultas Sains dan Teknologi, Universitas Islam Negeri Syarif Hidayatullah Jakarta.

[6] Davenport, Thomas H, Prusak L. 2000. Working Knowledge: How Organizations Manage What They 
Know. Boston: Harvard Business School Press.

[7] Rhem AJ. 2006. UML For Developing Knowledge Management Systems. Boca Raton New York : Taylor \&Francis Group.

[8] Gottschalk P. 2006. Stage of Knowledge Management Systems In Police Investigations. Knowledge Based Systems Journal. Vol 19: 381-387.

[9] Fernandez IB, Sabherwal R. 2010. Knowledge Management: System and Processes. England: M.E. Sharpe.

[10] Lai LF. 2007. A Knowledge Engineering Approach To Knowledge. Management. Information Sciences an international journal. Vol. 177: 40724094
[11] Martin EW, Brown CV, Dehayes DW, Hoffer JA, Perkins WC. 2005.Managing Information Technology. Prentice-Hall..

[12] Wijaya AE. 2014. Model Penerapan Knowledge Management System untuk Penyusunan Tugas Akhir Berbasis Teknologi Mobile Menggunakan J2ME (Studi Kasus STMIK SUBANG). Seminar Nasional Informatika UPN" Veteran" Yogyakarta. 1979-2328.

[13] Tan R. 2010. Perancangan Model Manajemen Pengetahuan menggunakan Model Nonaka Takeuchi ( Studi Kasus Administrasi Akademik). Jurnal Informatika Vol. 6 No. 1, Juni 2010:5164 